\title{
Effect of Palladium Form on Tetraphenylborate Decomposition
} Rate

by

D. D. Walker

Westinghouse Savannah River Company

Savannah River Site

Aiken, South Carolina 29808

This paper was prepared in connection with work done under the above contract number with the U.S. Department of Energy. By acceptance of this paper, the publisher and/or recipient acknowledges the U.S. Government's right to retain a nonexclusive, royalty-free license in and to any copyright covering this paper, along with the right to reproduce and to authorize others to reproduce all or part of the copyrighted paper. 


\section{DISCLAIMER}

This report was prepared as an account of work sponsored by an agency of the United States Government. Neither the United States Government nor any agency thereof, nor any of their employees, makes any warranty, express or implied, or assumes any legal liability or responsibility for the accuracy, completeness, or usefulness of any information, apparatus, product, or process disclosed, or represents that its use would not infringe privately owned rights. Reference herein to any specific commercial product, process, or service by trade name, trademark, manufacturer, or otherwise does not necessarily constitute or imply its endorsement, recommendation, or favoring by the United States Government or any agency thereof. The views and opinions of authors expressed herein do not necessarily state or reflect those of the United States Government or any agency thereof.

This report has been reproduced directly from the best available copy.

Available to DOE and DOE contractors from the Office of Scientific and Technical Information, P.O. Box 62, Oak Ridge, TN 37831; prices available from (615) 576-8401.

Available to the public from the National Technical Information Service, U.S. Department of Commerce; 5285 Port Royal Road, Springfield, VA 22161. 


\section{DISCLAIMER}

Portions of this document may be illegible in electronic image products. Images are produced from the best available original document. 
WSRC-TR-98-00073, Rev. 0

Keywords: In-Tank Process, Benzene

Retention: Permanent

\section{EFFECT OF PALLADIUM FORM ON TETRAPHENYLBORATE DECOMPOSITION RATE}

D. D. Walker

Publication Date: April 13, 1998

Westinghouse Savannah River Company Savannah River Technology Center Aiken, SC 29808

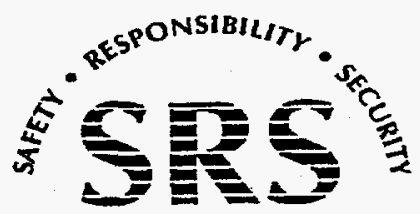


WSRC-TR-98-00073 Rev.0

Page 2 of 30

Tetraphenylborate Solids Stability Tests

Author

Darrel O. Waller

$4 / 13 / 98$

D. D. Walker, Waste Processing Technology

Date

Design Check

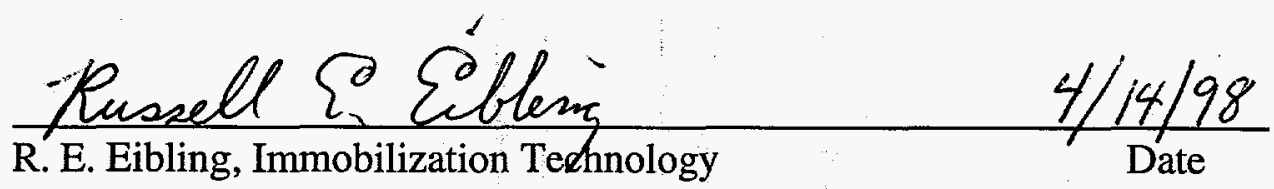
(per Manual E7, Procedure 2.40)

Approvals

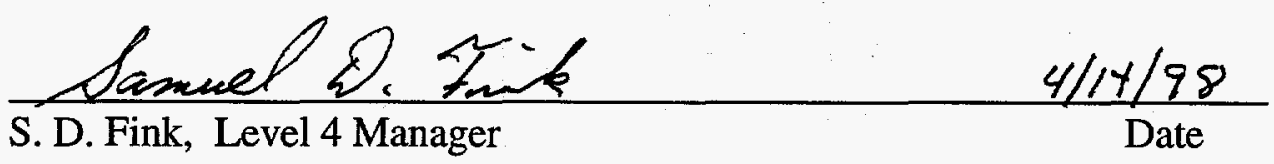

Waste Processing Technology

$\frac{\text { Sha Bane }}{\text { J. L. Barnes, Deputy Manager }}$

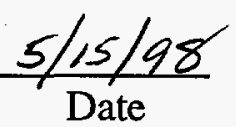

Waste Pretreatment Engineering
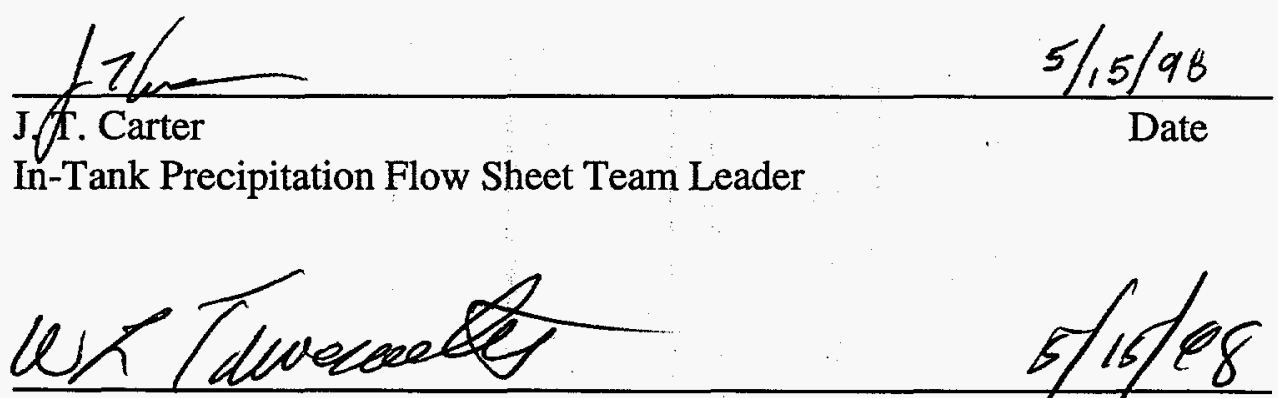

W. L. Tamosaitis, Level 3 Manager

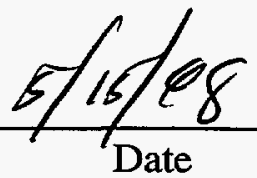
Waste Processing Technology 


\section{CONTENTS}

SUMMARY

INTRODUCTION........................................................................................... 5

TEST DESIGN AND RESULTS..................................................... 6

Palladium Form Test.................................................................. 6

Soluble Palladium Test........................................................................... 10

Solids Removal Test............................................................................ 11

DISCUSSION................................................................................................... 14

UNCERTAINTIES IN CURRENT WORK .............................. 15

ACKNOWLEDGEMENTS.............................................................. 17

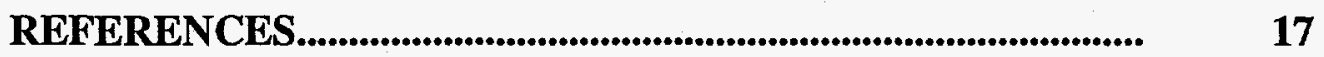

APPENDIX A: Postulated Mechanisms..........................................

APPENDIX B: Experimental............................................................. $\quad 22$ 


\section{LIST OF FIGURES}

$1 \quad$ Loss of TPB $^{-}$and Appearance of $\mathrm{K}^{+}$in Palladium Form Test........ 9

2 Appearance of $\mathrm{K}^{+}$in the Presence and Absence of Sludge Solids... 12

3 Decrease in Soluble Pd and Increase in $\mathrm{K}^{+}$in Filtered Test............. 12

$4 \quad$ Eh of an Alkaline Tetraphenylborate Slurry....................................... 16

$5 \quad$ Equilibrium Diagram for Palladium in Water at $25^{\circ} \mathrm{C}$..................... 16

\section{LIST OF TABLES}

I Summary of Fixed Conditions and Variables in the Pd

Form Test............................................................................................ 7

II Characteristics of Palladium Forms..................................................... 8

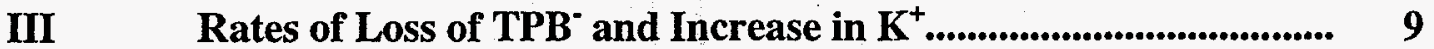

IV Distribution of Palladium......................................................................... $\quad 10$

V Comparison of Soluble Pd Concentrations and TPB-

Decomposition Rates................................................................................... 11

VI Comparison of Solid KTPB Decomposition Rates................. 13

VII Soluble Palladium Concentrations During Rapid Reaction.......... 15

VIII Selected Decomposition Rates and Soluble Palladium

Concentrations from KTPB Solids Stability Tests $\left(45^{\circ} \mathrm{C}\right)$............ 15

B-1 Composition of Simulated Waste Slurry......................................... 23

B-2 Catalyst Components in Simulant Slurries...................................... 24

B-3 Palladium Sources.................................................................................... 24

B-4 Concentrations of Selected Metals in Solubility Test of Four

Palladium Forms.................................................................................. 25

B-5 Composition of Salt Solution for Solids Removal Test........... 26

B-6 Analytical Results for Palladium Form Tests................................. 28

B-7 Analytical Results from Experiment on the Effect of Filtering Insoluble Sludge and Palladium........................................................... 29 


\title{
EFFECT OF PALLADIUM FORM ON TETRAPHENYLBORATE DECOMPOSITION RATE
}

\author{
By D. D. WALKER
}

\section{SUMMARY}

Palladium catalyzes the decomposition of tetraphenylborate in alkaline solutions. Researchers postulate several decomposition mechanisms that differ in the form of the palladium catalyst (see Appendix A). Potential forms include solid and soluble, different soluble species (such as aqueous or organic soluble), and different oxidation states (i.e., 0 , II, and IV). Initial tests measured the reactivity and distribution of four $\mathrm{Pd}$ forms in tetraphenylborate slurries. The four forms are aqueous-soluble $\mathrm{Pd}(\mathrm{II})$ nitrate, solid $\mathrm{Pd}^{0}$ supported on barium sulfate powder, solid $\mathrm{Pd}^{0}$ powder suspended in mercury, and solid $\mathrm{Pd}(\mathrm{II})$ oxide hydrate. The following points summarize the test results.

- Addition of aqueous soluble Pd(II) produced the most rapid decomposition reaction.

- Relative reactivities of the four Pd forms tested were:

$$
\mathrm{Pd}(\mathrm{II}) \text { nitrate }>\mathrm{Pd}\left(\mathrm{BaSO}_{4}\right) \sim \mathrm{Pd}(\mathrm{Hg})>\mathrm{PdO} \cdot \mathrm{H}_{2} \mathrm{O}
$$

- Soluble Pd(II) nitrate used in previous simulant tests proved the most reactive of the palladium forms tested.

- The reactive form of palladium appears to be $\mathrm{Pd}^{0}$.

- In reacting slurries, only a small fraction of the total palladium resides in the aqueous phase.

- In reacting and non-reacting systems, the palladium did not extract with benzene.

- In reacting systems, the majority of the palladium associates with the sludge and KTPB solids.

- Due to limitations in the extraction and separation methods, a Pd catalyst at the benzene-aqueous interface cannot be excluded. Similarly, a highly reactive soluble species that is a minor component in all of the palladium forms tested cannot be excluded.

\section{INTRODUCTION}

Previous studies indicated that palladium is a catalytically active component of rapidly decomposing alkaline tetraphenylborate slurries. ${ }^{1-5}$ Although statistical regression shows total palladium concentration as a significant factor in correlations of rate constants, the 
resulting expressions provide relatively poor fit to the data ${ }^{6}$ The mechanisms proposed to explain the experimental results differ in the form and location of the palladium catalyst (see Appendix A). The variability in results and the potential existence of different forms of palladium suggest that a variable fraction of the total palladium activates or that different forms of palladium exhibit widely varying reactivities. Improved understanding of the catalytic mechanism requires identification of the forms and distribution of palladium within the multiphase slurry system in addition to determining the relative reactivities of the different forms.

Tests described in this report represent an initial attempt to identify the chemical form and location of palladium in a reacting system. Information gained from these experiments could potentially explain the variability in previous testing, suggesting better measurements and variables to correlate the results.

This work fulfills a request from P. L. Rutland, "TPB Solids Stability," Technical Task Request \#HLE-TTR-98039, Rev.0, March 11, 1998. The work complies with the following plan: D. D. Walker, "Technical Task Plan for Solids Stability Studies of Tetraphenylborate Slurries - Additional Studies," WSRC-RP-98-00055, Rev.0, March 4, 1998.

\section{TEST DESIGN AND RESULTS}

Tests investigated (1) the effect of the form of palladium on the reaction rate, (2) the amount of soluble palladium in each form, and (3) the effect of removal of sludge and palladium solids on the reaction rate. The palladium form test compared the reactivity of soluble $\mathrm{Pd}(\mathrm{II})$ nitrate, solid $\mathrm{Pd}^{0}$ on barium sulfate particles, amalgamated $\mathrm{Pd}^{\circ}$, and $\mathrm{Pd}(\mathrm{II})$ oxide hydrate by measuring tetraphenylborate decomposition rates and palladium concentrations. The purpose of this test was to gain insight into the chemical form of the active catalyst. To help interpret the palladium form test, the fraction of the total palladium that was soluble in the simulant salt solution was measured for each of the four palladium forms. The differences in soluble palladium suggest an explanation for differences in the reactivities. The sludge removal test investigated the effect of removing insoluble sludge and palladium from the reaction mixture. This tests probes the source of the active palladium catalyst (i.e., soluble or insoluble palladium). Appendix B describes experimental details of the tests.

\section{Palladium Form Test}

\section{Test Design}

This test sought insight into the chemical form of the active palladium catalyst. The test obtained information in two ways. First, palladium was introduced in different forms and the rate of decomposition measured. Thus, the observed differences in reactivity may reflect the differences in form. Second, as the decomposition reaction progressed, 
TABLE I. Summary of Fixed Conditions and Variables in the Pd Form Test

\section{Fixed conditions}

Total palladium

Temperature

KTPB solids concentration

Sludge/ECC catalyst*

Atmosphere

Mixing

Vessels
$11 \mathrm{mg} / \mathrm{L}$

$45^{\circ} \mathrm{C}$

$60 \mathrm{~g} / \mathrm{L}(\sim 5 \mathrm{wt} \%)$

$12 \mathrm{~g} / \mathrm{L}(\sim 1$ wt $\%)$

sealed under air

no mixing

glass

\section{Palladium forms}

Test

1

2

3

4
Form

$\mathrm{Pd}(\mathrm{II})$ nitrate (40.0 wt \% $\mathrm{Pd}$ ), dissolved in $0.1 \mathrm{M} \mathrm{HNO}_{3}$.

$\mathrm{Pd}, 5$ wt $\%$ on $\mathrm{BaSO}_{4}$ powder, reduced

Pd black ( $\sim 5$ wt $\%$ oxygen), surface area $\sim 20 \mathrm{~m}^{2} / \mathrm{g}$, suspended in $\mathrm{Hg}^{0}$

Palladium(II) oxide hydrate, $\mathrm{PdO} \cdot \mathrm{H}_{2} \mathrm{O}, 78$ wt \% $\mathrm{Pd}$, dark brown, finely divided powder

* ECC $=$ Enhanced Comprehensive Catalyst. See Appendix B and Reference 5 for composition.

aliquots of slurry were extracted with benzene and separated into different phases (aqueous, KTPB solids, and sludge solids) to determine the location of the palladium.

Table I lists controlled test conditions and the forms of palladium examined. Table II lists chemical features of the different forms. The selection of forms provides a representative, but not exhaustive list of species possibly present for the various postulated mechanisms.

\section{Reaction Rates}

\section{$\underline{\text { Rate of Loss of TPB }}$}

Figure 1 shows the loss of tetraphenylborate during the 41-day test period. In all cases, decomposition occurred and different forms of palladium reacted at different rates. The order of reactivity was:

$$
\mathrm{Pd}(\mathrm{II}) \text { nitrate }>\mathrm{Pd}\left(\mathrm{BaSO}_{4}\right) \sim \mathrm{Pd}(\mathrm{Hg})>\mathrm{PdO} \cdot \mathrm{H}_{2} \mathrm{O}
$$

Table III lists quantitative estimates of the rates obtained from the initial slopes of the curves shown in Figure 1. Although the rates fall into three distinctly different ranges, the differences do not conclusively point to a particular form as the catalytic species. This could indicate that all four palladium forms will catalyze the reaction (but at different 


\section{TABLE II. Characteristics of Palladium Forms}

Pd(II) nitrate

Oxidation state:

Solubility:

Other:

$\operatorname{Pd}\left(\mathrm{BaSO}_{4}\right)$

Oxidation state:

Solubility:

Dispersion:

Other:

$\mathbf{P d}(\mathbf{H g})$

Oxidation state:

Solubility:

Dispersion:

Other:
$+2$

Soluble under aerobic conditions

Same form used in previous testing

0

Possibly minor amounts of $\mathrm{PdO}$ present

Insoluble in simulant

Distributed on $\mathrm{BaSO}_{4}$ particles, finely divided powder, surface area and particle size unknown

Selected for insolubility in aqueous system

\section{PdO hydrate}

Oxidation state:

Solubility:

Dispersion:

0 and +2

$62 \mathrm{wt} \% \mathrm{Pd}^{\circ}$ and 38 wt $\% \mathrm{PdO}$

Insoluble in simulant

Fine particles of $\mathrm{Pd}^{0}, \mathrm{Pd} 0$ and $\mathrm{PdHg}_{4}$ suspended in dispersed mercury droplets

Preparation method used 10-fold molar excess of $\mathrm{Hg}$ over $\mathrm{Pd} ; \mathrm{Pd}$ is sparingly soluble in $\mathrm{Hg}(0.005$ atom \% at $\left.25^{\circ} \mathrm{C}\right),{ }^{*} \mathrm{Pd}$ forms $\mathrm{PdHg}_{4}$ in excess $\mathrm{Hg}$;

$\mathrm{Hg} / \mathrm{Pd}$ atomic ratio in this test was approx. $2.5 \mathrm{X}$ normal ECC ratio

$+2$

Insoluble in simulant

Very fine powder, particle size unknown

*See Reference 8.

rates), that the catalytically active form is an impurity in the inactive forms, or that inactive forms convert to the catalytic form under the test conditions (forming different amounts of active catalyst). Table II lists some of the potential impurity forms. An example of conversion is the slow change from $\mathrm{PdO}$ hydrate to $\mathrm{Pd}^{0}$ under anoxic conditions. ${ }^{7}$

\section{Rate of Appearance of $\mathrm{K}^{+}$}

The tests with $\mathrm{Pd}(\mathrm{II})$ nitrate and $\mathrm{Pd}\left(\mathrm{BaSO}_{4}\right)$ consumed all of the initial $\mathrm{TPB}^{-}$and decomposed measurable amounts of KTPB before the test ended. Figure 1 shows the changes in potassium concentration and Table III lists the rates. Unexpectedly, the solids reaction with $\mathrm{Pd}$ (II) nitrate slowed and stopped after approximately 25 days with only $2.4 \%$ of the KTPB decomposed. In previous testing, solids reactions continued until more than $50 \%$ of the solids decomposed. 


\section{FIGURE 1. Loss of TPB' and Appearance of $\mathrm{K}^{+}$}
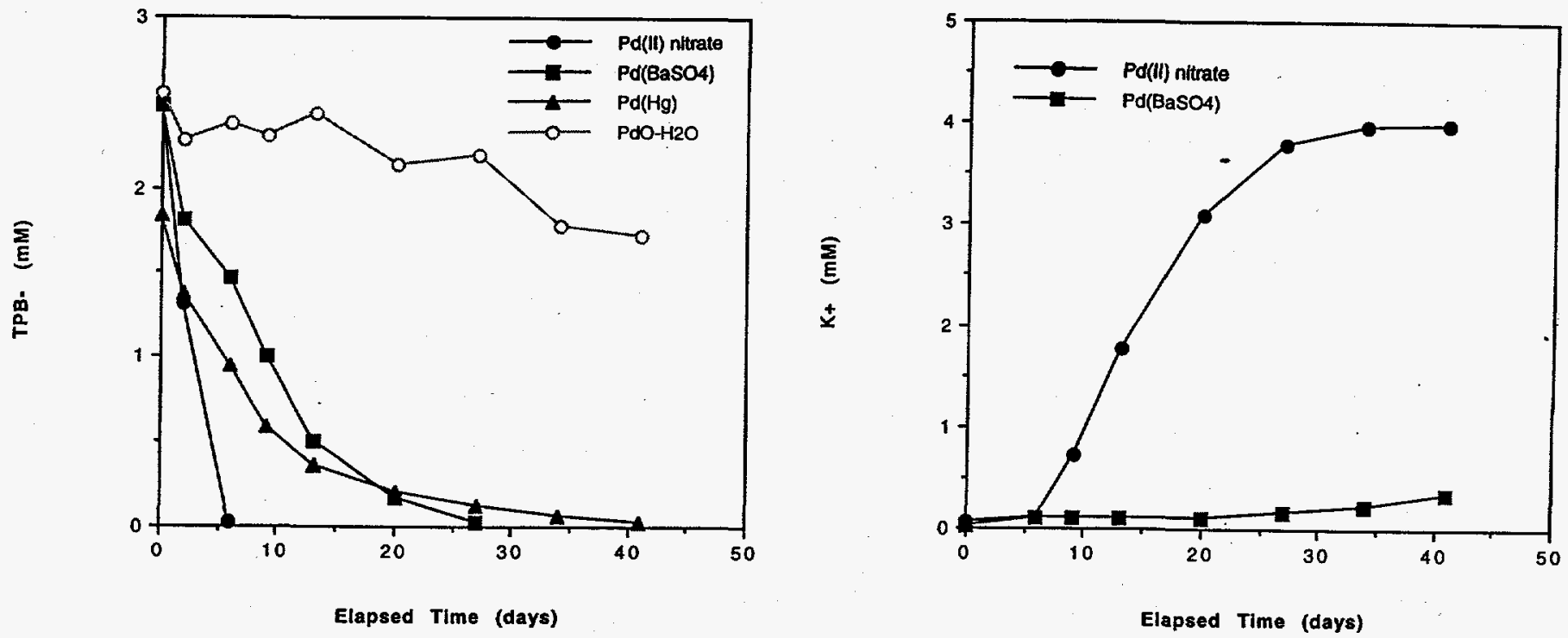

TABLE III. Rates of Loss of $\mathrm{TPB}^{-}$and Increase in $\mathrm{K}^{+}$

\begin{tabular}{lll} 
Form & \multicolumn{2}{c}{ Rate $(\mathrm{mM} / \mathrm{d})$} \\
& ${\underline{\mathrm{TPB}^{*}}}^{*}$ & $\underline{\mathrm{K}}^{+}$ \\
$\mathrm{Pd}(\mathrm{II})$ nitrate & 0.6 & 0.2 \\
$\left.\mathrm{Pd}(\mathrm{BaSO})_{4}\right)$ & 0.3 & 0.01 \\
$\mathrm{Pd}(\mathrm{Hg})$ & 0.2 & $* *$ \\
PdO hydrate & 0.02 & $* *$
\end{tabular}

*Based on initial slopes.

** No reaction during test duration.

\section{Palladium Distribution}

The recoveries of palladium from slurry samples were low and erratic, so conclusions from the results are tentative. Table IV lists the results for the distribution of palladium in the slurries. Recoveries average 63\% and varied from 19 to $86 \%$. Most of the recoveries exceeded $50 \%$, but two were particularly low (19 and 29\%). The low and erratic recoveries may reflect sampling error in obtaining a portion of the slurry from the reaction vessel. However, the author believes significant improvement could result from refining the extraction and separation techniques. 


\section{TABLE IV. Distribution of Palladium}

\begin{tabular}{|c|c|c|c|c|c|c|}
\hline \multirow[t]{2}{*}{ Form } & \multirow{2}{*}{$\begin{array}{r}\text { Time } \\
\text { (days) }\end{array}$} & \multirow{2}{*}{$\begin{array}{l}\text { Recovery* } \\
\quad(\%)\end{array}$} & \multicolumn{4}{|c|}{ Distribution (\% of recovered) } \\
\hline & & & Aqueous & Benzene & $\underline{\mathrm{KTPB}}$ & Sludge \\
\hline \multirow{3}{*}{$\begin{array}{l}\mathrm{Pd}(\mathrm{II}) \\
\text { nitrate }\end{array}$} & 0 & 72 & 49 & 1 & 44 & 6 \\
\hline & 13 & 19 & 11 & 1 & 68 & 21 \\
\hline & 34 & 73 & 5 & 0.1 & 84 & $11^{-}$ \\
\hline \multirow{3}{*}{$\mathrm{Pd}\left(\mathrm{BaSO}_{4}\right)$} & 0 & 86 & 6 & 0.1 & 48 & 46 \\
\hline & 13 & 52 & 4 & 0.2 & 42 & 54 \\
\hline & 34 & 74 & 7 & 0.1 & 82 & 11 \\
\hline \multirow[t]{3}{*}{$\mathrm{Pd}(\mathrm{Hg})$} & 0 & 81 & 2 & 0.1 & 57 & 41 \\
\hline & 13 & 76 & 0.3 & 0.1 & 96 & 4 \\
\hline & 34 & 29 & 12 & 0.3 & 66 & 21 \\
\hline \multirow[t]{3}{*}{$\mathrm{PdO} \mathrm{H}_{2} \mathrm{O}$} & 0 & 87 & 2 & 0 & 60 & 38 \\
\hline & 13 & 50 & 4 & 0.2 & 76 & 20 \\
\hline & 34 & 60 & 10 & 0.2 & 15 & 75 \\
\hline
\end{tabular}

*The theoretical amount of palladium in each sample was $110 \mu \mathrm{g}$.

The recovered palladium resided primarily in the solid phases (50 to 100\%), typically with more in the KTPB than in the sludge. Lesser portions ( 0.3 to $12 \%$ ) of the palladium were found in the aqueous phase, except in the first sample from the $\mathrm{Pd}$ (II) nitrate test (49\%). Subsequent aqueous samples from the $\mathrm{Pd}(\mathrm{II})$ nitrate tests decreased in soluble palladium. Researchers found this pattern (i.e., drop in aqueous soluble Pd during reaction) in previous studies. ${ }^{9,10}$ Very little of the palladium was found in the benzene extracts $(0.1 \%$ to $1 \%)$. The distribution was similar in all four tests and did not differ notably between reactive and non-reactive slurries.

\section{Soluble Palladium Test}

The soluble fraction of the total palladium was measured for each of the four palladium forms used in the reactivity tests. In separate experiments, researchers placed each source material into a $2.8 \mathrm{M} \mathrm{Na}^{+}, 0.8 \mathrm{M} \mathrm{OH}^{-}$salt solution at $\sim 23^{\circ} \mathrm{C}$. In each case, the total palladium added was $11 \mathrm{mg} / \mathrm{L}$. All components of the ECC catalyst system were added except NaTPB, KTPB, 3PB, 2PB, 1PB, and benzene. The concentrations of palladium and several other metals were measured after 7 and 14 days. Table $V$ lists the palladium concentrations. The results for other metals are listed in Appendix B, Table B-4. The concentrations listed in Table V should not be considered solubility limits since the tests were not run long enough to verify equilibrium was achieved. The soluble palladium 
TABLE V. Comparison of Soluble Pd Concentrations and TPB' Decomposition Rates

\begin{tabular}{|c|c|c|c|c|}
\hline \multirow[t]{2}{*}{ Test } & \multirow[t]{2}{*}{$\underline{\text { Pd Form }}$} & \multicolumn{2}{|c|}{ Soluble Pd (mg/L)* } & \multirow{2}{*}{$\begin{array}{l}\text { TPB Rate }^{* * *} \\
(\mathrm{mM} / \mathrm{d})\end{array}$} \\
\hline & & 7 days & 14 days & \\
\hline 1 & $\operatorname{Pd}(I I)$ nitrate & 10.2 & 9.3 & 0.6 \\
\hline 2 & $\mathrm{Pd}\left(\mathrm{BaSO}_{4}\right)$ & 0.65 & 1.7 & 0.3 \\
\hline 3 & $\mathrm{Pd}(\mathrm{Hg})$ & 0.022 & 0.042 & 0.2 \\
\hline 4 & PdO hydrate & 0.085 & 0.18 & 0.02 \\
\hline
\end{tabular}

* Measured in a non-reactive system without phenyl borate compounds present.

** From Table III, measured from reacting systems.

concentrations increased between the first and second week in three of the four forms. The most soluble form, Pd(II) nitrate, decreased slightly, although the two measurements may reflect analytical uncertainty more than a change in concentration. The soluble palladium concentration does not correlate well with the decomposition rate.

\section{Solids Removal Test}

The effect of removing insoluble sludge and palladium prior to precipitation of KTPB solids was examined as a potential method for removing part or all of the catalytic palladium. In this test, a salt solution was stirred for a week with the sludge and palladium. In this test, the palladium was originally added to the sludge as $\operatorname{Pd}(\mathrm{II})$ nitrate solution, but it had been in contact with the alkaline sludge slurry for almost four years, possibly allowing time for conversion of the soluble palladium to other forms. After stirring at ambient temperature $\left(22 \pm 3^{\circ} \mathrm{C}\right)$, the soluble palladium concentration was $6.4 \mathrm{mg} / \mathrm{L}$ after 3 days and did not change significantly between 3 and 7 days. The salt solution was divided in half and the sludge removed from one of the halves by filtration. KTPB was precipitated in both the filtered and unfiltered portions of the salt solution, and the resulting slurries were incubated at $45^{\circ} \mathrm{C}$. The loss of NaTPB, increase in soluble $\mathrm{K}^{+}$, and palladium concentration were monitored periodically for 52 days. Figure 2 shows the results of these measurements. Removal of the sludge and palladium solids did not significantly effect the final rate of decomposition, although it appears to have delayed the onset of the reaction by about two weeks. The rates of increase in potassium ion for the two tests were: filtered, $0.69 \mathrm{mM} \mathrm{K}^{+} / \mathrm{d}$; and unfiltered (with sludge) $0.66 \mathrm{mM} / \mathrm{d}$. In both cases, the soluble palladium concentration dropped to less than $0.1 \mathrm{mg} / \mathrm{L}$ within the first 12 days following the precipitation of the KTPB. Figure 3 shows the loss of palladium in the filtered test in comparison to the rise in potassium. The unfiltered test with sludge and Pd solids present showed similar changes in soluble palladium (see Appendix, Table B-6). The drop in palladium concentration at time zero was due to 
FIGURE 2. Appearance of $\mathrm{K}^{+}$in the Presence and Absence of Sludge Solids

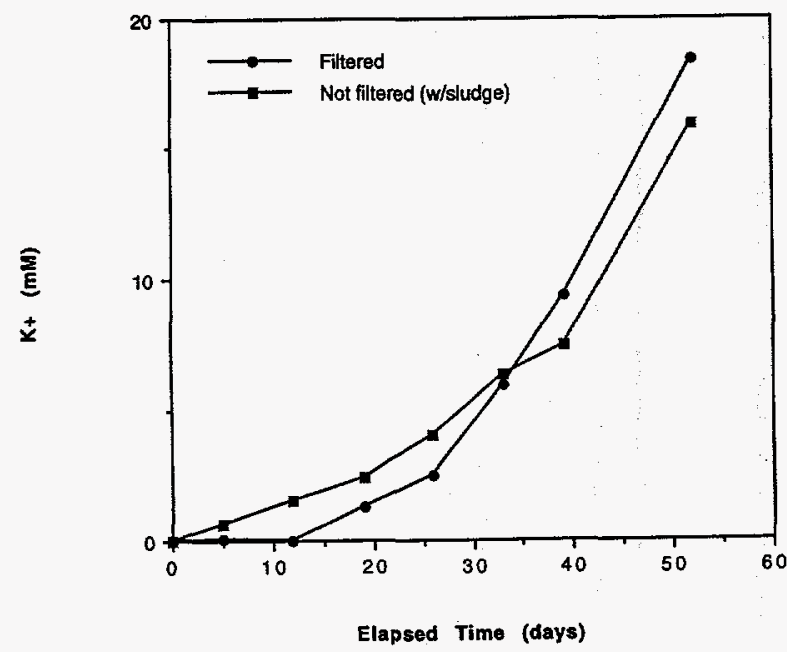

FIGURE 3. Decrease in Soluble Pd and Increase in $\mathrm{K}+$ in Filtered Test

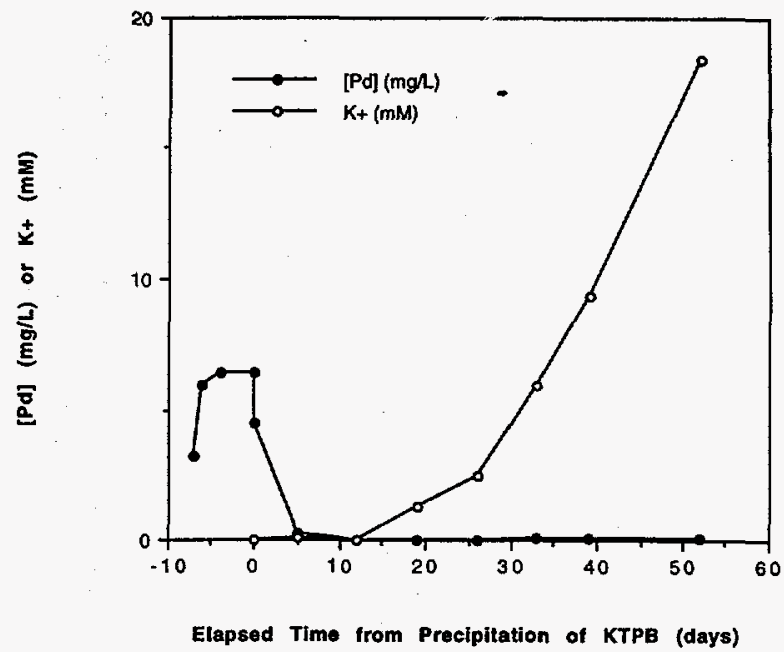

dilution caused by addition of NaTPB solution to precipitate KTPB. The decrease in soluble palladium was coincident with the decomposition of the soluble tetraphenylborate. The initial soluble Pd concentration in these tests $(4.5 \mathrm{mg} / \mathrm{L}$, see Appendix B, Table B-6) was significantly higher than the soluble Pd concentration in real waste tests $(\leq 0.26 \mathrm{mg} / \mathrm{L}){ }^{11}$

The near equivalence in rate between the filtered and unfiltered tests suggests that the source of the active catalyst is the soluble palladium. The relative activity can be estimated knowing (1) half of the palladium was insoluble and (2) the decomposition rates differed by less than $10 \%$. Thus the insoluble palladium is less than $10 \%$ as active as the soluble form (or produces less than $10 \%$ of the amount of active catalyst as does the soluble Pd).

The rate of decomposition of solid KTPB was faster in both tests than in previous tests at comparable hydroxide ion concentration. ${ }^{9,10}$ Table VI lists the results of current and previous tests. The rate of decomposition of soluble TPB $^{-}$was not calculated due to insufficient data. Over the $\mathrm{pH}$ range of 10 to 14.5 , the solids decomposition rate correlates with the $\mathrm{pH}$. Previous studies showed the rate decreases as the $\mathrm{pH}$ (or hydroxide ion concentration ) increases. ${ }^{9-10}$ However, the lack of correlation between $\mathrm{pH}$ and rate of appearance of $\mathrm{K}^{+}$in Table VI suggests the rate is affected by another variable. 


\begin{tabular}{|c|c|c|c|c|c|}
\hline \multirow[b]{2}{*}{$\begin{array}{l}{\left[\mathrm{OH}^{-}\right]} \\
\underline{(\mathbf{M})}\end{array}$} & \multirow[b]{2}{*}{$\begin{array}{c}{\left[\mathrm{Na}^{+}\right]} \\
(\mathrm{M})\end{array}$} & \multirow[b]{2}{*}{ Other** } & \multicolumn{3}{|c|}{ Decomposition Rate } \\
\hline & & & $\begin{array}{c}\mathbf{K}^{+} \\
(\mathbf{m M} / \mathbf{d}) \\
\end{array}$ & $\begin{array}{c}\mathrm{K}^{+} \\
(\mathrm{mg} / \mathrm{L} / \mathrm{d}) \\
\end{array}$ & $\begin{array}{l}\text { Benzene* } \\
(\mathrm{mg} / \mathrm{L} / \mathrm{h})\end{array}$ \\
\hline 1.5 & 2.8 & This report, filtered & 0.66 & 25.8 & 8.6 \\
\hline 1.5 & 2.8 & This report, unfiltered & 0.69 & 27.0 & 9.0 \\
\hline 3.0 & 4.5 & Ref. 10 , Test 3 & 0.27 & 10.5 & 3.5 \\
\hline 1.8 & 5.5 & Ref. 10 , Test 1 & 0.15 & 5.8 & 1.9 \\
\hline 1.5 & 4.5 & Ref. 10 , Test 4 & 0.18 & 7.1 & 2.4 \\
\hline 0.6 & 5.5 & Ref. 10 , Test 2 & 0.43 & 16.8 & 5.6 \\
\hline 1.5 & 5.5 & Ref. 9, Test 1 & 0.10 & 3.8 & 1.3 \\
\hline
\end{tabular}

* Calculated from rate of increase in $\mathrm{K}^{+}$assuming 4 moles of benzene are produced from each mole of $\mathrm{K}^{+}$. ** The solids removal test and the Ref. 9 results were obtained using palladium aged with alkaline sludge metals for approximately 3 years prior to use. The Ref. 10 results were obtained using palladium from an acidic palladium nitrate solution added at the start of the test. Total palladium concentrations were similar (10-13 $\mathrm{mg} \mathrm{Pd} / \mathrm{L})$ in all tests.

The current tests differed from previous tests in the following ways: (1) the contact time between sludge, palladium, and salt solution was longer (one week in these tests compared to 2 hours in other simulant tests), (2) the sodium ion concentration during precipitation of KTPB was higher ( 3.5 molar initially versus 0.4 molar), and (3) the KTPB solids were precipitated in the presence of the sludge and palladium. The solids removal test conditions (e.g., higher salt concentration and presence of sludge solids during KTPB precipitation) were more representative of process operations than previous simulant tests.

Contact time with the highly alkaline salt solution and other sludge metals may affect the oxidation state, hydration state, or distribution of the palladium thus influencing the amount or activity of the palladium catalyst. High sodium ion concentration during KTPB precipitation may produce smaller crystals with different surface characteristics. Precipitation of KTPB in the presence of the sludge and palladium may either affect the crystal morphology (if sludge particles act as nucleating sites for KTPB) or the distribution of palladium on (or among) KTPB solids. The difference in contact time is likely not the reason for the high rates in the solids removal test. Aging of the palladium in the presence of alkaline sludge was suggested as a potential reason why the Reference 10 rates were more rapid than Reference 9 (Table VI). However, the other two differences could produce a more finely distributed catalyst (and thus a more active catalyst per gram of palladium) compared to previous tests. 


\section{DISCUSSION}

Several pieces of evidence suggest that the active catalyst is a solid, low valent palladium species. This evidence includes the following observations.

- Less than $10 \%$ of the total palladium is found in the aqueous phase during rapid reaction.

- Solids decomposition rates do not correlate with soluble palladium concentrations.

- The majority of the palladium is associated with the sludge and KTPB solids.

- Reaction occurs with highly insoluble, low-valent forms of palladium (i.e., $\mathrm{Pd}\left(\mathrm{BaSO}_{4}\right)$ and $\left.\mathrm{Pd}(\mathrm{Hg})\right)$.

- Soluble palladium(II) converts to insoluble $\mathrm{Pd}^{0}$ under alkaline, anoxic conditions. $^{7}$

- When only soluble palladium is present, it converts to an insoluble form during the initial reaction phase.

The first two points above suggest that the active catalyst is not an aqueous soluble form: (1) most of the palladium is not aqueous soluble, and (2) the rate of reaction is not proportional to the soluble Pd concentration. Even though the fastest reaction occurred with the most soluble form of $\mathrm{Pd}$ (i.e., with $\mathrm{Pd}(\mathrm{II})$ nitrate where the initial soluble Pd concentration was $3.5 \mathrm{mg} / \mathrm{L}, 7$ to 15 times higher than the others), the measured soluble Pd concentrations during the time period of rapid reaction (9-21 days) were comparable to the slower reactions (Table VII). The reaction rates varied by 30x whereas the soluble Pd differed by $<2 \mathrm{x}$. Table VIII lists pertinent data from previous solids stability tests. ${ }^{9,10}$ The table groups tests with similar sodium and hydroxide concentrations. Not only does there appear to be no correlation between decomposition rate and soluble palladium, but neither is there a correlation with initial palladium or change in soluble palladium. There is no palladium data available to correlate with reaction rates for soluble NaTPB.

The observation that addition of soluble Pd(II) nitrate produces the most rapid reaction appears contrary to the suggestion that the active catalyst is a solid, low valent palladium species. However, it is supported by the following arguments based on results from decomposition of solid tetraphenylborates. ${ }^{9-10}$ First, when palladium is added in the soluble form, most of it does not remain in solution. In many cases where the initial soluble palladium is high, the concentration decreases prior to rapid decomposition. In all cases, insoluble palladium was present initially or was produced from soluble palladium early in the test. Second, the most stable form of palladium in alkaline tetraphenylborate slurries is $\mathrm{Pd}^{0}$. The stable oxidation state is determined largely by the solution $\mathrm{pH}$ and Eh. Alkaline tetraphenyhlborate slurries have $\mathrm{pH}$ values between 12 and 14.7 and Eh values of approximately $-600 \mathrm{mV}$ (Figure 4). ${ }^{12}$ Figure 5 shows the thermodynamically stable phases of palladium over a wide range of $\mathrm{pH}$ and $\mathrm{Eh}$. The $\mathrm{pH}$ and Eh conditions in simulants indicate that $\mathrm{Pd}(\mathrm{II})$ would reduce to the most stable form, $\mathrm{Pd}^{0}$. In fact, the slurries are so strongly reducing that palladium hydride may be the most stable form, suggesting additional decomposition mechanisms. 
TABLE VII. Soluble Palladium Concentrations During Rapid Reaction

Form

Pd(II) nitrate

$\mathrm{Pd}\left(\mathrm{BaSO}_{4}\right)$

$\operatorname{Pd}(\mathrm{Hg})$

PdO hydrate
Soluble Pd Concentration $(\mathrm{mg} / \mathrm{L})$

$\frac{9 \text { days }}{0.55} \quad \frac{13 \text { days }}{0.22} \quad \frac{20 \text { days }}{0.10}$

0.42

0.21

0.12

0.42

0.23

0.11

0.42

0.24

0.18

TABLE VIII. Selected Decomposition Rates and Soluble Palladium Concentrations from KTPB Solids Stability Tests $\left(45^{\circ} \mathrm{C}\right)$

\begin{tabular}{|c|c|c|c|c|c|c|c|}
\hline \multicolumn{3}{|c|}{$\operatorname{Pd}(\mathrm{mg} / \mathrm{L})$} & \multicolumn{2}{|c|}{$\mathrm{K}^{+}$Rate } & \multirow[t]{2}{*}{$\underline{\mathrm{pH}}$} & \multirow{2}{*}{$\begin{array}{l}\mathrm{Na}^{+} \\
\text {(M) }\end{array}$} & \multirow[t]{2}{*}{$\underline{\text { Ref. }}$} \\
\hline Initial & Change & Final & $\underline{\mathrm{mM} / \mathrm{c}}$ & $(\mathrm{mg} / \mathrm{L} / \mathrm{d})$ & & & \\
\hline 4.9 & -1.3 & 3.6 & 0.66 & 26 & 10.5 & 5.5 & 9 \\
\hline 14. & -12.8 & 1.2 & 3.2 & 124 & 10.7 & 5.5 & 9 \\
\hline 3.8 & +2.8 & 6.6 & 0.56 & 22 & 10.2 & 2.8 & 9 \\
\hline 3.4 & -1.7 & 1.7 & 0.36 & 14 & 9.9 & 2.8 & 9 \\
\hline 4.1 & -3.9 & 0.2 & 0.49 & 19 & 10.5 & 2.8 & 9 \\
\hline 5.7 & +1.8 & 7.5 & 0.056 & 2.2 & 10.2 & 0.1 & 9 \\
\hline 2.3 & -1.6 & 0.6 & 0.59 & 23 & 10.3 & 0.1 & 9 \\
\hline 0.1 & -0.1 & $<0.1$ & 0.43 & 17 & 10.4 & 0.1 & 9 \\
\hline 3.1 & +6.9 & 10. & 0.074 & 2.9 & 14.5 & 5.5 & 9 \\
\hline 7.4 & -7.2 & 0.2 & 0.097 & 3.8 & 14.5 & 5.5 & 9 \\
\hline 8.6 & -8.4 & 0.2 & 0.15 & 5.8 & 14.3 & 5.5 & 10 \\
\hline 1.8 & -1.5 & 0.3 & 0.22 & 8.5 & 14.2 & 4.5 & 0 \\
\hline 10.7 & -10.6 & 0.1 & 0.26 & 10.1 & 14.5 & 4.5 & 0 \\
\hline 5.5 & -5.4 & 0.1 & 0.18 & 7.1 & 14.2 & 4.5 & 10 \\
\hline
\end{tabular}


FIGURE 4. Eh of Alkaline

Tetraphenylborate Slurry

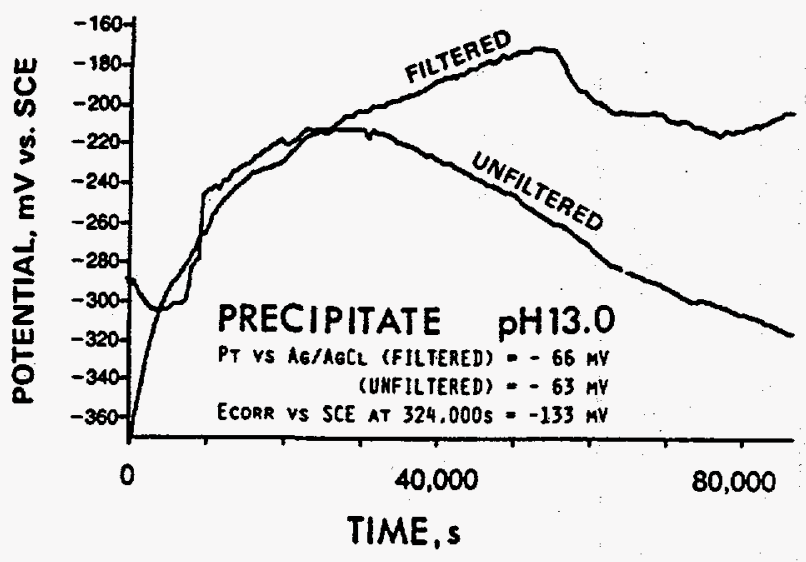

Note: The standard calomel electrode (SCE) is $-282 \mathrm{mV}$ vs. the standard hydrogen electrode.
Figure 5. Stability Diagram for Palladium

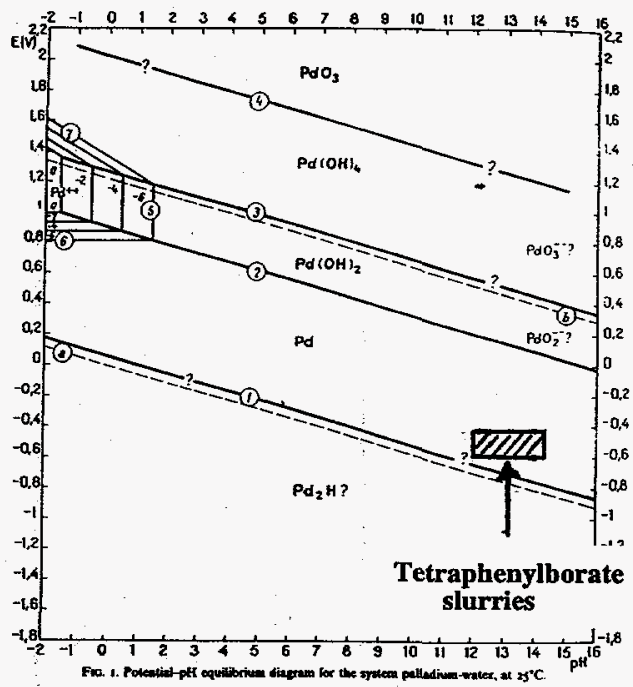

(from M. Pourbair, Reference 13)

By the arguments above, $\mathrm{PdO}$ hydrate should convert to $\mathrm{Pd}^{0}$ and catalyze the reaction. However the rate of conversion of $\mathrm{PdO}$ hydrate to $\mathrm{Pd}^{0}$ under anoxic conditions is slow and the conversion is incomplete after six months under anoxic conditions. ${ }^{7}$ Thus, the difference in reactivity between soluble $\mathrm{Pd}(\mathrm{II})$ and insoluble $\mathrm{PdO}$ hydrate may be due to their relative rates of conversion of $\mathrm{Pd}^{0}$.

Identification of the active catalyst as a low valent species is supported by the reactivity of the two zero-valent forms tested and the thermodynamic stability of $\mathrm{Pd}^{0}$ under the test conditions. It is also supported by the observed distribution in which the majority of the total palladium is found with the tetraphenylborate and sludge solids.

The presence of large amounts of palladium with the tetraphenylborate solids and failure to remove palladium by benzene extraction suggests that the catalytic form is not a benzene soluble compound. This result must be considered tentative since other factors could have intervened to prevent extraction. The extraction procedure successfully removed mercury, presumably in the form of diphenylmercury. However, if the catalytic palladium compound is distributed differently or is more strongly adsorbed on tetraphenylborate solids, the extraction could have failed for a palladium compound. Tests on the distribution of benzene in KTPB slurries indicate that shaking by hand may not be sufficient to wet the KTPB particles with benzene within the time period used in the test. ${ }^{14}$ In addition, the extraction procedure introduces oxygen into the slurry sample and could have changed the oxidation state (and, thus, the distribution and extractability) of the palladium compound. 
Although the observations suggest an insoluble palladium catalyst, they do not preclude a soluble form at the benzene-water interface. In the benzene extraction procedure, small amounts of benzene (including, presumably, the interface) remained with the solids. Thus, an interfacial palladium compound could have been left with the solids

Another interpretation of the results is that only a small fraction of the total palladium is catalytically active. In this interpretation, the experimental results are inconclusive since some palladium was found in each of the phases analyzed, including the benzene phase.

\section{UNCERTAINTIES IN CURRENT WORK}

The results of the experiments suggest that the palladium catalyst is an insoluble lowvalent compound. If additional understanding of the catalyst system is needed, future testing should include the following areas of investigation.

- Determine the distribution and form of palladium in SRS radioactive wastes.

The rate of decomposition of tetraphenylborate and the methods suitable for removing palladium are sensitive to the amount and form of the palladium present. Before deciding on methods for palladium removal, the distribution of palladium in the SRS wastes should be explored.

- Determine the rate of conversion and final form of soluble Pd(II) nitrate under experimental conditions.

When $\mathrm{Pd}(\mathrm{II})$ nitrate is added to tetraphenylborate slurries, the majority converts to an insoluble form. XRD could be used to identify the final form and possibly further characterize the insoluble forms of palladium used in tests reported here.

- Measure the catalytic activity of other forms of palladium.

This is an extension of the work described in this report. Tests with additional forms might provide additional information on the identity of the active catalyst. Additional forms are available commercially, including palladium dispersed on activated carbon. This approach could be extended to include the synthesis of low-valent Pd compounds that are stable under the test conditions.

\section{ACKNOWLEDGEMENTS}

The author wishes to acknowledge the helpful discussions and suggestions from John R. Fowler in the design and interpretation of the experiments described in this report. 


\section{REFERENCES}

1. M. J. Barnes, C. L. Crawford, and C. A. Nash, "Sodium Tetraphenylborate Catalyst Identification: Preliminary Studies Set 1 (U)," WSRC-TR-97-0060, Rev.0, March 6, 1997.

2. M. J. Barnes, "Sodium Tetraphenylborate Catalyst Identification: Preliminary Studies Set 2 (U),"WSRC-TR-97-0144, Rev.0, May 28, 1997.

3. M. J. Barnes and R. A. Peterson, "Sodium Tetraphenylborate Catalyst Identification: Phase A Statistical Design Studies (U),” WSRC-TR-97-0210, Rev.0, July 22, 1997.

4. M. J. Barnes and R. A. Peterson, "Sodium Tetraphenylborate Catalyst Identification: Phase B and C Statistical Design Studies (U)," WSRC-TR-97-0230, Rev.0, August 13, 1997.

5. M. J. Barnes, "Sodium Tetraphenylborate Catalyst Identification: Phase D Statistical Design Studies (U)," WSRC-TR-97-0275, Rev.0, September 5, 1997.

6. R. A. Peterson and T. B. Edwards, "Statistical Investigation into the Decomposition Rates of Tetraphenylborate and its Daughter Compounds (U)," WSRC-TR-97-00403, Rev.0, December, 1997.

7. C. Oda, H. Yoshikawa, and M. Yui, "Effects of Aging on the Solubility of Palladium," Mat.Res.Soc.Symp.Proc., Vol.412, Materials Research Society, 1996, p.881.

8. C. Hirayama, Z. Galus, and C. Guminski, Solubility Data Series, Metals in Mercury, Vol.25, Pergamon, Oxford, p 326-329.

9. D. D. Walker and T. B. Edwards, "Tetraphenylborate Solids Stability Tests (U)," WSRC-TR-97-0285, Rev.0, December 19, 1997.

10. D. D. Walker, "ITP Solids Stability Operating Window Tests," WSRC-TR-98-00072, Rev.0, March 18, 1998.

11. D. T. Hobbs, M. J. Barnes, R. A. Peterson, C. L. Crawford, S. J. Emory, "Radioactive Testing Results in Support of the In-Tank Precipitation Facility," WSRC-TR-98-00070, Rev.0, April 2, 1998.

12. D. F. Bickford, J. W. Congdon, and S. B. Oblath, "Corrosion of Radioactive Waste Tanks Containing Washed Sludge and Precipitates," Materials Performance, 27(5), 16 (1988).

13. M. J. N. Pourbaix, Atlas of Electrochemical Equilibria in Aqueous Solutions, Cebelcor, Brussels, 1963, p 358. 
14. L. O. Dworjanyn, "Benzene Retention in TPB Slurry - Status Report (U)," WSRC-RP97-217, March 26, 1997.

15. L. L. Tovo and W. T. Boyce, "Analysis of Copper in the In-Tank Precipitation Process Caustic Samples (U),” WSRC-TR-96-0400, December 12, 1996. 
APPENDIX A

Postulated Mechanisms

The following eight decomposition mechanisms have been postulated.

Mechanism 1. Aqueous-Soluble Catalyst and Aqueous- Soluble Substrate

Decomposition occurs when the aqueous-soluble palladium catalyst reacts with soluble $\mathrm{TPB}^{-}$ion. Solid tetraphenylborates must dissolve to react with catalyst. The rate will depend on the concentration of soluble palladium and TPB', but will be independent of solids.

\section{Mechanism 2. Micellular Catalyst and Aqueous-soluble Substrate}

The palladium catalyst is a polar molecule, presumably with a phenyl groups at one end and hydroxo groups opposite. The catalyst resides at the benzene aqueous interface. Soluble TPB ${ }^{-}$approaches the catalyst from the aqueous side of the interface to react. The rate of reaction depends on the presence of benzene and solids (to disperse the benzene phase), the concentration of aqueous TPB-, but is independent of aqueous soluble

\section{Mechanism 3. Benzene-soluble Catalyst and Benzene-soluble Substrate}

The palladium catalyst (possibly a phenylated, neutral species) is soluble in a benzene layer distributed over the slurry solids. The catalyst reacts with TPB ion (or ion pair) dissolved in the benzene phase. Benzene-soluble substrate could come from extraction of aqueous $\mathrm{TPB}^{-}$ion or dissolution of tetraphenylborate solids.

\section{Mechanism 4. Benzene-soluble Catalyst and Solid Substrate}

The catalyst is dissolved in a benzene phase distributed over the surface of the tetraphenylborate solids. The catalyst reacts primarily at the solid surface. The reaction rate will depend on the presence of benzene and tetraphenylborate solids, but would be independent of soluble TPB $^{-}$or aqueous soluble palladium.

\section{Mechanism 5. Solid Catalyst and Benzene-soluble Substrate}

A solid palladium catalyst (insoluble in water or benzene) is coated with benzene and reacts with $\mathrm{TPB}^{-}$dissolved in the benzene. The presence of the benzene phase promotes removal of 3PB from the activated complex as a phenyl anion remains with the palladium catalyst. 


\section{Mechanism 6. Solid Catalyst and Aqueous-soluble Substrate}

Decomposition occurs when $\mathrm{TPB}^{-}$in the aqueous phase encounters the solid phase palladium catalyst. During reaction, $\mathrm{Pd}$ might not be detectable in the aqueous phase, but the rate would depend very strongly on the soluble $\mathrm{TPB}^{-}$concentration.

\section{Mechanism 7. Aqueous-soluble Catalyst and Solid Substrate}

The soluble catalyst reacts at the surface of the tetraphenylborate solids. In this mechanism, the reaction rate should be independent of the concentration of soluble TPB-

\section{Mechanism 8. Solid catalyst and Solid Substrate}

Both the palladium catalyst and tetraphenylborate solids react as solids. This is a very unlikely mechanism since the reaction rate would be exceedingly slow due to limited reaction zone where the two solids contact. 


\section{APPENDIX B \\ Experimental}

\section{Preparation of Slurries}

Researchers prepared a simulated KTPB slurry (nominally 5 wt \% KTPB solids) with the composition shown in Table B-1. Researchers added $\sim 0.8 \mathrm{M}$ NaTPB solution to a $\sim 0.15$ $\mathrm{M} \mathrm{KNO}_{3}$ solution to ensure complete and rapid precipitation of KTPB, followed by addition of soluble sodium salts to achieve $2.8 \mathrm{M} \mathrm{Na}^{+}$. All chemicals were reagent grade. NaTPB ( $99+\%$ purity) came from Aldrich Chemical Company. Next, all of the components of the catalyst system (Table B-2) except palladium, benzene, diphenylmercury, and the alcohols were added to the slurry. The slurry was then split into four $175-\mathrm{mL}$ portions. To each portion of slurry was added one of the palladium forms (Table B-3). Enough of the palladium form was added to achieve $11 \mathrm{mg}$ Pd per liter of slurry. After stirring for one hour, approximately $130 \mathrm{~mL}$ of slurry were placed in 150$\mathrm{mL}$ glass serum bottles, the benzene, diphenylmercury, and alcohols were added, the vials were capped with Teflon-lined serum caps, and placed in an oven at $55^{\circ} \mathrm{C}\left( \pm 3{ }^{\circ} \mathrm{C}\right)$. The remaining slurry in the Erlenmeyer flask was used for the initial (zero time) sample. The vials were maintained at temperature, sealed, and unstirred for the duration of the test. Periodically, the vials were removed from the oven, shaken briefly by hand, and sampled by syringe.

The $\mathrm{Pd}(\mathrm{Hg})$ mixture was prepared as follows:

(1) $1.9 \mathrm{mg}$ of $\mathrm{Pd}$ black, $62 \mathrm{mg}$ of $\mathrm{Hg}\left(\mathrm{NO}_{3}\right)_{2} \cdot \mathrm{H}_{2} \mathrm{O}$, and $1 \mathrm{~g}$ water were weighed into a glass beaker. The mixture was stirred to dissolve the mercuric nitrate and suspend the palladium black.

(2) $82 \mathrm{mg}$ of $\mathrm{SnCl}_{2}-2 \mathrm{H}_{2} \mathrm{O}$ were dissolved in $1 \mathrm{~mL}$ water, then added to the $\mathrm{Pd}$ and mercury mixture to reduce the $\mathrm{Hg}(\mathrm{II})$ to $\mathrm{Hg}^{0}$.

(3) The mixture was stirred overnight and the entire contents added to one portion of the slurry.

At all sampling times, a portion of slurry was filtered using disposable acrylic copolymer syringe filters ( 0.45 micron nominal pore size) (Gelman Sciences) and the filtrate analyzed for soluble metals, NaTPB, and decomposition products. Three times during the test, a second sample $(\sim 10 \mathrm{~g})$ was taken and placed in a centrifuge tube. Benzene (15 $\mathrm{mL}$ ) was added and the mixture shaken by hand for 5 minutes. The benzene was separated by centrifuging and decanting. The benzene extraction was repeated three more times using $10-\mathrm{mL}$ aliquots of benzene. The benzene extracts $(45 \mathrm{~mL})$ were evaporated to dryness and the residue submitted for analysis. Due to the density of the salt solution, the sludge solids sank to the bottom of the centrifuge tube while the KTPB solids floated on the surface. The KTPB solids and salt solution were removed and filtered. Water $(\sim 5$ $\mathrm{mL}$ ) was used to facilitate removal of all the KTPB solids from the centrifuge tube and rinse the solids. The solids were dried at $45^{\circ} \mathrm{C}$ and submitted for analysis. The sludge was removed from the centrifuge tube by suspending in water and transferring to a glass beaker. The sludge and water were dried at $45^{\circ} \mathrm{C}$ and the residue analyzed. 


\section{Soluble Palladium Test}

A test was run to determine the amount of palladium that dissolves from the four palladium forms under air in the absence of tetraphenylborate and intermediate decomposition products. Table B-1 lists the salt solution composition. It corresponds to the average composition of soluble waste at the Savannah River Site. The ECC catalyst system (Table B-2) was added at $1 \mathrm{wt} \%$, including inactive organics (methanol, isopropanol, and phenol), but not benzene, tetraphenylborate, or decomposition intermediates (3PB, 2PB, and 1PB). Palladium was added from the same sources used in the reactivity tests (Table B-3). To $100 \mathrm{~mL}$ portions of the salt solution and ECC catalyst, enough of the Pd source was added to produce $11 \mathrm{mg}$ Pd per liter. The solutions were stirred at room temperature and sampled after 7 and 14 days. The samples were filtered using 0.45 micron acrylic copolymer syringe filters (Gelman Sciences) and analyzed for selected metals by ICP-MS. The results are listed in Table B-4.

TABLE B-1 Composition of Simulated Waste Slurry (Excluding Catalyst Components)*

\begin{tabular}{lc} 
Component & Concentration (molar) \\
\cline { 1 - 2 } $\mathrm{Na}^{+}$ & 2.8 \\
$\mathrm{OH}^{-}$ & 0.84 \\
$\mathrm{NO}_{3}{ }^{-}$ & 1.06 \\
$\mathrm{NO}_{2}^{-}$ & 0.39 \\
$\mathrm{AlO}_{2}{ }^{-}$ & 0.17 \\
$\mathrm{CO}_{3}{ }^{2-}$ & 0.08 \\
$\mathrm{SO}_{4}{ }^{2-}$ & 0.07 \\
$\mathrm{Cl}^{-}$ & 0.013 \\
$\mathrm{~F}$ & 0.008 \\
$\mathrm{PO}_{4}{ }^{3-}$ & 0.005 \\
$\mathrm{TPB}^{-}$ & 0.002 \\
& \\
$\mathrm{KTPB}$ & $60 \mathrm{~g} / \mathrm{L}(\sim 5 \mathrm{wt} \%)$
\end{tabular}

*See Table B-2 for catalyst components. 


\section{TABLE B-2. Catalyst Components in Simulant Slurries}

Insoluble Components (wt $\%$ of slurry)

$1.2 \mathrm{~g} / \mathrm{L}(\sim 1 \mathrm{wt} \%)$ sludge

$1.2 \mathrm{~g} / \mathrm{L}(\sim 1 \mathrm{wt} \%)$ monosodium titanate

Sludge composition (wt \% of dry sludge):

$\begin{array}{ll}\mathrm{Al} & 4.8 \\ \mathrm{Fe} & 18.8 \\ \mathrm{Mn} & 5.9 \\ \mathrm{Ru} & 0.23 \\ \mathrm{Rh} & 0.06 \\ \mathrm{Cr} & 0.2\end{array}$

Metal Additives ( $\mathrm{mg} / \mathrm{L})$

$\mathrm{Ca}$ (II) $\quad 12.2$

Sr(II) $\quad 0.1$

La(III) $\quad 0.05$

$\mathrm{Ce}$ (IV) $\quad 0.3$

$\mathrm{Cu}$ (II) $\quad 1.7$

$\mathrm{Ag}(\mathrm{I}) \quad 0.6$

$\mathrm{Zn}(\mathrm{II}) \quad 8.8$

Organic Additives (mg/L)

$\begin{array}{ll}\text { 3PB } & 500 \\ \text { 2PB } & 250 \\ \text { Phenol } & 250 \\ \text { Benzene } & 750\end{array}$

500

250

750

$\begin{array}{ll}\mathrm{Ru}(\mathrm{III}) & 0.8 \\ \mathrm{Co}(\mathrm{II}) & 0.04 \\ \mathrm{Rh}(\mathrm{III}) & 0.2 \\ \mathrm{Sn}(\mathrm{III}) & 2.1 \\ \mathrm{~Pb}(\mathrm{II}) & 1.2 \\ \mathrm{As}(\mathrm{IV}) & 0.04 \\ \mathrm{Se}(\mathrm{VI}) & 1\end{array}$

Cd(II) $\quad 0.4$

$\mathrm{Hg}(\mathrm{II}) \quad 2.2$

Si(IV) 16

Cr(VI) 60

Mo(VI) 12 .

$\mathrm{Fe}(\mathrm{III}) \quad 2.6$

TABLE B-3. Palladium Sources

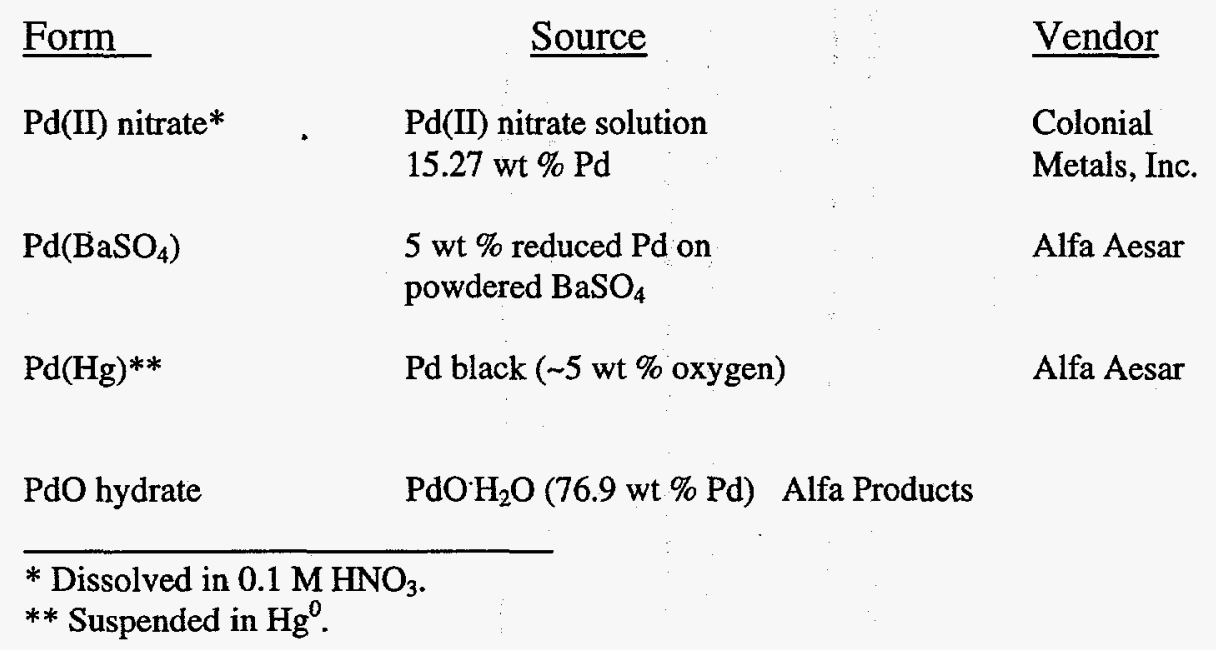

$\begin{array}{lr}\text { Diphenylmercury } & 150 \\ \text { Methanol } & 4 \\ \text { Isopropanol } & 40\end{array}$

0.1

- 0.1

2.5

0.3

0.2

2.5
50

40 
TABLE B-4. Concentrations of Selected Metals in Solubility Test of Four Palladium Sources

\begin{tabular}{|c|c|c|c|c|c|}
\hline & Elapsed & & & & \\
\hline & Time & & Concentra & (L) & \\
\hline Metal & (d) & $\underline{\mathrm{Pd}\left(\mathrm{NO}_{3}\right)_{2}}$ & $\underline{\mathrm{Pd}\left(\mathrm{BaSO}_{4}\right)^{*}}$ & $\underline{\mathrm{PdO}^{*}}$ & $\underline{\mathrm{Pd}(\mathrm{Hg})^{*}}$ \\
\hline $\mathrm{Pd}$ & 7 & 10.2 & 0.65 & 0.085 & 0.022 \\
\hline & 14 & 9.3 & 1.70 & 0.180 & 0.042 \\
\hline $\mathrm{Cu}$ & 7 & 0.117 & 0.129 & 0.130 & 0.139 \\
\hline & 14 & 0.179 & 0.193 & 0.202 & 0.200 \\
\hline $\mathrm{Hg}$ & 7 & 0.52 & 0.57 & 0.67 & 0.100 \\
\hline & 14 & 0.54 & 0.69 & 0.73 & 0.125 \\
\hline $\mathrm{Ag}$ & 7 & 0.036 & 0.060 & 0.032 & $<.020$ \\
\hline & 14 & 0.81 & 0.57 & 0.43 & 0.35 \\
\hline $\mathrm{Ru}$ & 7 & 0.030 & $<.020$ & 0.028 & $<.020$ \\
\hline & 14 & 0.036 & 0.033 & 0.036 & 0.036 \\
\hline $\mathrm{Rh}$ & 7 & 0.042 & 0.031 & 0.042 & 0.020 \\
\hline & 14 & 0.010 & 0.011 & 0.014 & 0.018 \\
\hline
\end{tabular}

* See Table B-3 for description of palladium sources.

\section{Solids Removal Test}

Researchers prepared a salt solution containing $3.53 \mathrm{M} \mathrm{Na}^{+}$with the same relative distribution of anions currently found in Tank $48 \mathrm{H}$ but without organic compounds (Table B-5). The components of the ECC catalyst system (Table B-2) were added ( $1 \mathrm{wt} \%$ catalyst) except for the organic components. The sludge contained $0.11 \mathrm{wt} \%$ palladium. The palladium was added to the sludge metals in January 1994 and the sludge was used for this experiment in October 1997. The total palladium concentration in the sludge and salt solution slurry was $13 \mathrm{mg} / \mathrm{L}$. The slurry was stirred at ambient temperature $\left(22 \pm 3{ }^{\circ} \mathrm{C}\right)$ for seven days. Samples were removed, filtered, and analyzed after 5 minutes, 1 day, 3 days, and 7 days. After seven days, the salt solution was divided into two parts and one part was filtered to remove the insoluble sludge components. Sodium tetraphenylborate $(0.55 \mathrm{M})$ was added to each half to precipitate soluble potassium and produce $60 \mathrm{~g}$ KTPB per liter. Addition of the ECC catalyst components and the NaTPB solution diluted the total sodium concentration to 2.8 molar and the composition shown in Table B-1. The organic components of the catalytic system (see Table B-2) were added to both slurries and the resulting mixtures incubated at $45^{\circ} \mathrm{C}$ for 
WSRC-TR-98-00073 Rev.0

Page 26 of 30

TABLE B-5. Composition of Salt Solution for Solids Removal Test

Component

$\mathrm{Na}^{+}$

$\mathrm{OH}^{-}$

$\mathrm{NO}_{3}^{-}$

$\mathrm{NO}_{2}^{-}$

$\mathrm{AlO}_{2}^{-}$

$\mathrm{CO}_{3}^{2-}$

$\mathrm{SO}_{4}^{2-}$

$\mathrm{Cl}^{-}$

$\mathrm{F}$

$\mathrm{PO}_{4}{ }^{3-}$
Concentration (M)

After KTPB Precipitation

Initial

3.53

1.93

0.87

0.32

0.13

0.064

0.060

2.8

1.5

0.69

0.25

0.10

0.051

0.048

0.008

0.005

0.003

52 days. Periodically, portions were removed, filtered, and analyzed for loss of NaTPB, increase in soluble $\mathrm{K}^{+}$, and concentrations of soluble heavy metals ( $\mathrm{Ag}, \mathrm{Ru}, \mathrm{Rh}$, and $\mathrm{Pd}$ ).

\section{Analytical Results}

The samples were analyzed for potassium ion, organic compounds (NaTPB, 3PB, 2PB, $1 \mathrm{~PB}$, and phenol), and metals ( $\mathrm{Cu}, \mathrm{Hg}, \mathrm{Ag}, \mathrm{Ru}, \mathrm{Rh}$, and Pd). Table B-6 lists the analytical results from the palladium form test, Table III lists results from the solubility test, and Table B-7 lists results from the test on the effect of filtering to remove insoluble palladium and sludge.

\section{Analytical Methods}

The following analyses were performed by the Analytical Development Section of SRTC.

Phenylboronic acid (1PB) and phenol were measured by high performance liquid chromatography (HPLC) on a Hewlett Packard LC with a $2.1 \times 250 \mathrm{~mm}$ Dychrom Chemosorb 5-ODS-UH column using acetonitrile-water eluent.

Tetraphenylborate, triphenylboron (3PB), and diphenylborinic acid (2PB) were measured on the same model instrument and column using a $0.1 \%$ ammonium phosphate buffered acetonitrile-methanol-water eluent (La-mar-ka, Inc., Baton Rouge, LA). The HPLC instrument methods are described in Manual L16.1, Procedure \#ADS-2655. The methodology of sample preparation, standards, and standard preparation for HPLC analyses is described in SRT-ADS-96-0438. A control solution was submitted with each set of samples to verify consistent performance of the HPLC method. The control samples contained NaTPB, 1PB and phenol. The results for the controls were consistently within $\pm 10 \%$ of the average. 
Potassium ion concentrations on aqueous samples were measured by flame atomic absorption using a Varian SpectrAA-400 spectrometer. The samples were first digested in nitric acid by microwave heating. Each digested sample was diluted 1:4(sample:suppressant) in a suppressant solution of $2000 \mu \mathrm{g} / \mathrm{mL}$ cesium. For more concentrated samples, additional dilutions were made with $1600 \mu \mathrm{g} / \mathrm{mL}$ cesium. The method is described in Manual L16.1, Procedure \#ADS-1549.

Copper concentrations were measured by Inductively Coupled Plasma Emission Spectroscopy (ICPES) using an ARL 3580 instrument. Samples for copper were diluted 10X and acidified to a pH less than or equal to 2 using $5 \mathrm{wt} \%$ nitric acid. The methods are described in Manual L16.1, Procedure \#ADS-1509 and in Reference 15.

Silver, ruthenium, rhodium, and palladium were measured using a Fisons PQS-974 ICPMS according to the method described in Manual L16.1, Procedure \#ADS-1553. The salt solution samples were diluted by a factor of 100 with dilute nitric acid prior to analysis.

Solid samples were digested completely and diluted to constant volume for analysis. The benzene extract samples were digested in nitric acid with microwave heating. KTPB and sludge solids were digested by sodium peroxide fusion followed by uptake in hydrochloric acid. 
TABLE B-6. Analytical Results for Palladium Form Tests

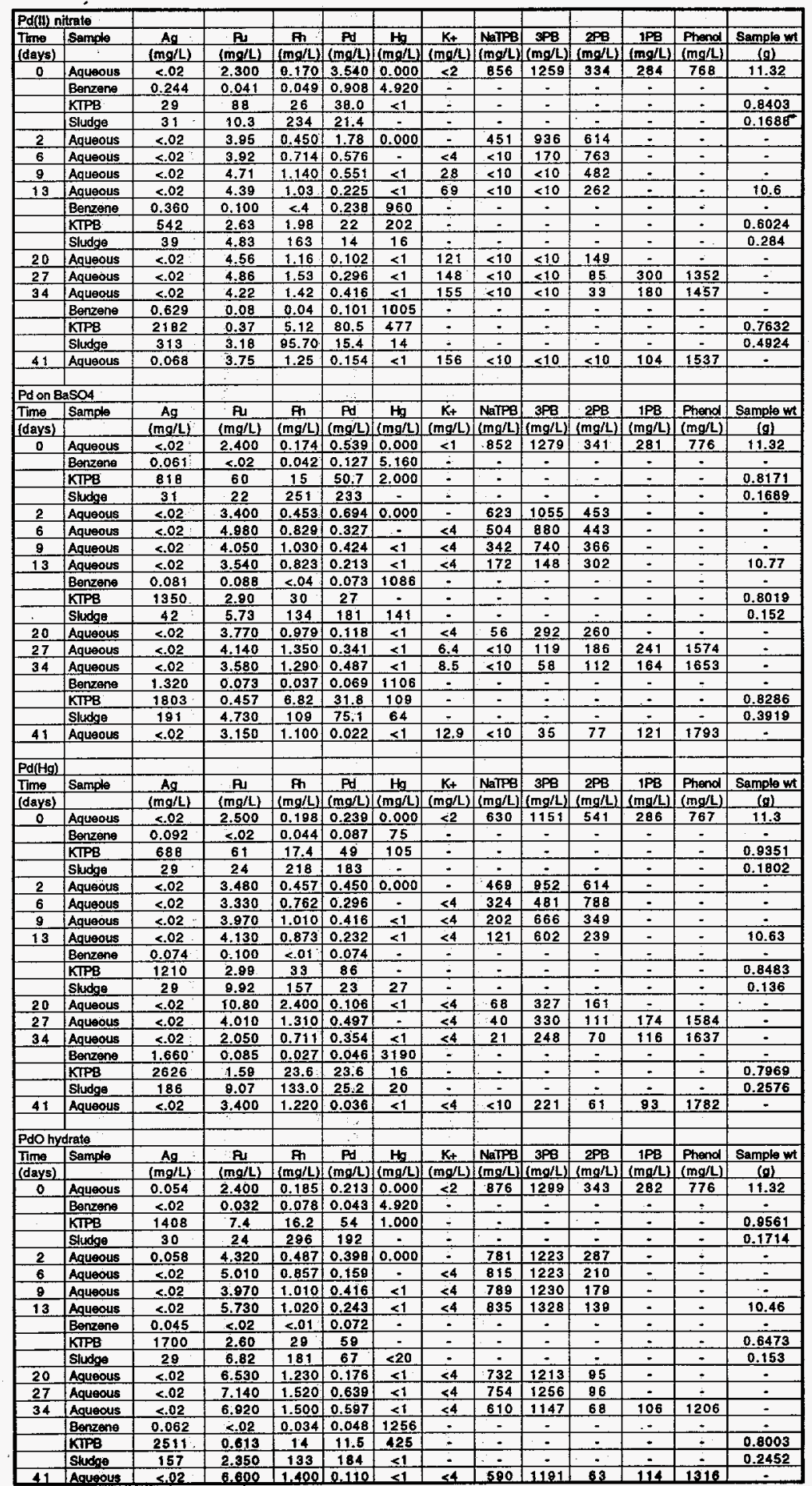


TABLE B-7. Analytical Results from Experiment on the Effect of Filtering Insoluble Sludge and Palladium

\begin{tabular}{|c|c|c|c|c|c|c|c|c|c|c|}
\hline \multicolumn{11}{|c|}{ Metal concentrations in salt solution prior to KTPB precipitation $\left(23{ }^{\circ} \mathrm{C}\right)$} \\
\hline \multirow[t]{2}{*}{ Elapsed Time } & & & & & a & $\mathrm{Hg}$ & $\mathrm{Ag}$ & Ru & $\mathrm{Fn}$ & $P d$ \\
\hline & . & & & & $(\mathrm{mg} / \mathrm{L})$ & $(\mathrm{mg} / \mathrm{L})$ & $(\mathrm{mg} / \mathrm{L})$ & $(\mathrm{mg} / \mathrm{L})$ & $(\mathrm{mg} / \mathrm{L})$ & $(\mathrm{mg} / \mathrm{L})$ \\
\hline $5 \mathrm{~min}$ & & & & & 0.13 & 0.044 & 0.07 & 0.37 & 0.04 & 3.2 \\
\hline 1 day & & & & & 0.082 & 0.059 & 0.09 & 0.70 & 0.08 & 5.9 \\
\hline 3 days & & & & & 0.081 & 0.043 & 0.07 & 0.66 & 0.11 & 6.4 \\
\hline 7 days & & & & & 0.072 & 0.16 & $<.05$ & 0.50 & 0.13 & 6.4 \\
\hline & & & & & & & & & & \\
\hline \multicolumn{11}{|c|}{ Slurry from filtered salt solution (no insoluble sludge) } \\
\hline Elapsed Time & $K_{+}$ & 4PB & 3PB & $2 \mathrm{~PB}$ & $1 \mathrm{~PB}$ & Phenol & $\mathrm{Ag}$ & $\mathrm{Pu}$ & Fn & $\mathrm{Pd}$ \\
\hline (days) & $(\mathrm{mg} / \mathrm{L})$ & $(\mathrm{mg} / \mathrm{L})$ & $(\mathrm{mg} / \mathrm{L})$ & $(\mathrm{mg} / \mathrm{L})$ & $(\mathrm{mg} / \mathrm{L})$ & $(\mathrm{mg} / \mathrm{L})$ & $(\mathrm{mg} / \mathrm{L})$ & $(\mathrm{mg} / \mathrm{L})$ & $(\mathrm{mg} / \mathrm{L})$ & $(\mathrm{mg} / \mathrm{L})$ \\
\hline 0 & $<.2$ & 425 & 834 & 201 & 244 & 276 & $<.05$ & 0.31 & 0.10 & 4.5 \\
\hline 5 & 3 & 24 & 566 & 611 & 303 & 307 & $<.05$ & 0.26 & 0.08 & 0.240 \\
\hline 12 & $<1$ & $<10$ & 178 & 834 & 368 & 347 & $<.02$ & 0.29 & 0.03 & 0.039 \\
\hline 19 & 51 & $<10$ & 34 & 889 & 502 & 418 & $<.02$ & 0.30 & 0.10 & 0.035 \\
\hline 26 & 98 & $<10$ & $<10$ & 882 & 738 & 595 & 24.80 & 0.31 & 0.12 & 0.038 \\
\hline 33 & 231 & $<10$ & $<10$ & 436 & 1027 & 878 & 0.12 & 0.30 & 0.11 & 0.064 \\
\hline 39 & 367 & $<10$ & $<10$ & 203 & 1169 & 1188 & $<.02$ & 0.29 & 0.14 & 0.083 \\
\hline 52 & 720 & $<10$ & $<10$ & 61 & 1326 & 1885 & $<.02$ & 0.25 & $<.01$ & 0.063 \\
\hline \multicolumn{11}{|c|}{ Slurry with sludge solids present } \\
\hline Elapsed Time & $\mathrm{K}+$ & $4 \mathrm{~PB}$ & 3PB & $2 \mathrm{~PB}$ & $1 \mathrm{~PB}$ & Phenol & $\mathrm{Ag}$ & $\mathrm{Ru}$ & Fh & $\mathrm{Pd}$ \\
\hline (days) & $(\mathrm{mg} / \mathrm{L})$ & $(\mathrm{mg} / \mathrm{L})$ & $(\mathrm{mg} / \mathrm{L})$ & $(\mathrm{mg} / \mathrm{L})$ & $(\mathrm{mg} / \mathrm{L})$ & $(\mathrm{mg} / \mathrm{L})$ & $(\mathrm{mg} / \mathrm{L})$ & $(\mathrm{mg} / \mathrm{L})$ & $(\mathrm{mg} / \mathrm{L})$ & $(\mathrm{mg} / \mathrm{L})$ \\
\hline 0 & $<.2$ & 867 & 869 & 211 & 245 & 290 & $<.05$ & 0.39 & 0.12 & 4.1 \\
\hline 5 & 26 & $<10$ & 13 & 283 & 939 & 338 & $<.05$ & 1.41 & 0.29 & 0.02 \\
\hline 12 & 60 & $<10$ & $<10$ & 95 & 935 & 383 & $<.02$ & 1.46 & 0.43 & 0.03 \\
\hline 19 & 93 & $<10$ & $<10$ & 61 & 797 & 473 & $<.02$ & 1.64 & 0.47 & 0.02 \\
\hline 26 & 157 & $<10$ & $<10$ & 75 & 740 & 617 & $<.02$ & 1.59 & 0.56 & 0.026 \\
\hline 33 & 249 & $<10$ & $<10$ & 63 & 600 & 732 & 0.046 & 1.46 & 0.56 & 0.038 \\
\hline 39 & 291 & $<10$ & $<10$ & 62 & 452 & 832 & $<.02$ & 1.54 & 0.56 & 0.061 \\
\hline 52 & 623 & $<10$ & $<10$ & 100 & 645 & 1398 & $<.02$ & 1.42 & 0.46 & 0.065 \\
\hline
\end{tabular}


CC: J. L. Barnes, 704-56H

M. J. Barnes, 773-A

T. K. Bragg, 241-197H

T. E. Britt, 703-H

J. N. Brooke, 773-A

J. D. Carlson, 703-H

J. T. Carter, 704-56H

G. L. Cauthen, 241-119H

W. C. Clark, 704-56H

C. L. Crawford, 773-41A

D. E. Doughty, 704-56H

R. E. Eibling, 704-T

H. H. Elder, 704-S

S. D. Fink, 773-A

J. R. Fowler, 703-H

R. C. Fowler, 241-152H

F. R. Graham, 773-A

M. S. Hay, 773-A

H. F. Herrera, 703-H

J. R. Hester, 703-H

M. J. Hitchler, CCC-3

D. T. Hobbs, 773-A

E. W. Holtzscheiter, 773-A

R. A. Jacobs, 704-T

M. E. Jamison, 703-H

M. D. Johnson, 703-H

M. T. Keefer, 704-56H

P. S. Kirkland, 703-46A

L. F. Landon, 704-T

B. L. Lewis, 703-H

T. J. Lex, 703-H

P. E. Lowe, 773-41A

D. J. McCabe, 773-43A

J. W. McCullough, 703-H

M. S. Miller, 704-56H

J. P. Morin, 703-H

C. A. Nash, 773-42A

L. M. Nelson, 773-43A

L. M. Papouchado, 773-A

R. A. Peterson, 773-A

S. F. Piccolo, 704-56H
C. T. Randall, 704-T

P. L. Rutland, 704-56H

R. M. Satterfield, 703-H

A. B. Scott, 703-H

W. E. Stevens, 773-A

P. C. Suggs, 703-H

R. F. Swingle, 773-A

W. L. Tamosaitis, 773-A

G. L. Taylor, 703-H

J. K. Thomas, CCC-3

W. B. VanPelt, 773-42A

D. D. Walker, 773-A

W. C. Walker, CCC-3

W. R. Wilmarth, 773-42A

A. L. Wooten, CCC-3

G. T. Wright, 773-A

WPT-LWG Files,

c/o A. Patterson, 773-A

ITP Files c/o A.G. Wiest,241-119H

TIM(4), 703-43A

RECORD ADMINISTRATION, 773-52A 